\title{
Seawater injection barrier recharge with advanced reclaimed water at Llobregat delta aquifer (Spain)
}

\author{
F. Ortuño, J. Molinero, T. Garrido and E. Custodio
}

\begin{abstract}
$\overline{\text { ABSTRACT }}$
The main aquifer of the Llobregat delta (Barcelona, Spain) has been affected by seawater intrusion since the 1960s. The Catalan Water Agency (ACA) has sponsored the construction of a positive hydraulic barrier in order to stop the progress of seawater intrusion advance due to the intensive aquifer development. The hydraulic barrier consists of 15 wells into which highly treated reclaimed water from the waste water treatment plant of the Baix Llobregat is injected. Water is subjected, prior to the distribution to the injection wells, to secondary and tertiary treatments, and later to ultrafiltration, UV disinfection without chlorination, and salinity reduction through reverse osmosis. A preliminary pilot phase of the project was started in late 2007, with highly positive results, and the second phase started in mid 2010. Hydrogeological and hydrochemical monitoring data indicate an efficient performance and aquifer improvement. The evaluation of such efficiency and operational costs has been analyzed and discussed.
\end{abstract}

Key words | artificial recharge, coastal zones, groundwater overexploitation, hydraulic barrier, Llobregat delta aquifer, reclaimed water, seawater intrusion

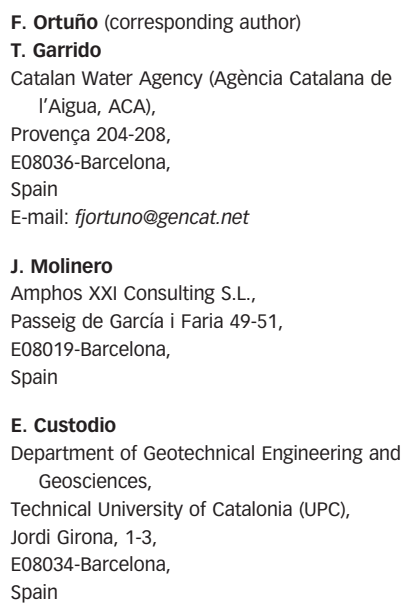

\section{GENERAL FRAME AND APPROACH}

\section{The aquifers of the lower valley and delta of the Llobregat}

The geology of the Llobregat delta is well known as many studies were carried out by the Water Administration in the 1960s that were followed by several others (Marqués I984; Manzano I993; Simó et al. 2005; Gámez 2007). The Llobregat delta is formed by a silt and clay wedge deposited under an estuarine environment that separates two sand and gravel aquifers: an upper one, $15 \mathrm{~m}$ thick, of Holocene age; and a deeper aquifer, 10 to $20 \mathrm{~m}$ thick, of late Pleistocene age, which is the main and most important aquifer (Figure 1). This deep aquifer is confined and very transmissive (1,000 to $5,000 \mathrm{~m}^{2} /$ day). Abstracted water is primarily used for urban and industrial supply. It is a strategic water resource for supplying Barcelona and its metropolitan area in droughts and emergency situations (Niñerola et al. 2009).

\section{Seawater intrusion}

Seawater intrusion processes have been observed in the main delta aquifer since the 1960s (Iribar \& Custodio doi: $10.2166 /$ wst.2012.423
1992). The intensive exploitation of groundwater resources, along with the excavation of part of the confining layer in the eastern coastal corner, has led to the progressive deterioration of groundwater quality (Custodio I98I, 2008, 20I0; Iríbar I992; Iríbar et al. I997; Abarca et al. 2006). Two main seawater intrusion fronts exist, one in the central coastal area and the other in the easternmost part (Figure 2). Current groundwater abstraction is approximately $54 \mathrm{Mm}^{3}$ /year, but it exceeded $100 \mathrm{Mm}^{3} /$ year in the 1970 s. The sustainable exploitation rate to avoid further groundwater deterioration is calculated to be around $40 \mathrm{Mm}^{3} /$ year for the current well distribution (Vázquez-Suñé et al. 2006).

\section{THE LLOBREGAT HYDRAULIC INJECTION BARRIER}

\section{Project configuration and objectives}

The Catalan Water Agency (ACA), along with the Groundwater Users' Community, the Metropolitan Agency for Hydraulic Services and Waste Treatment (EMSHTR) and 


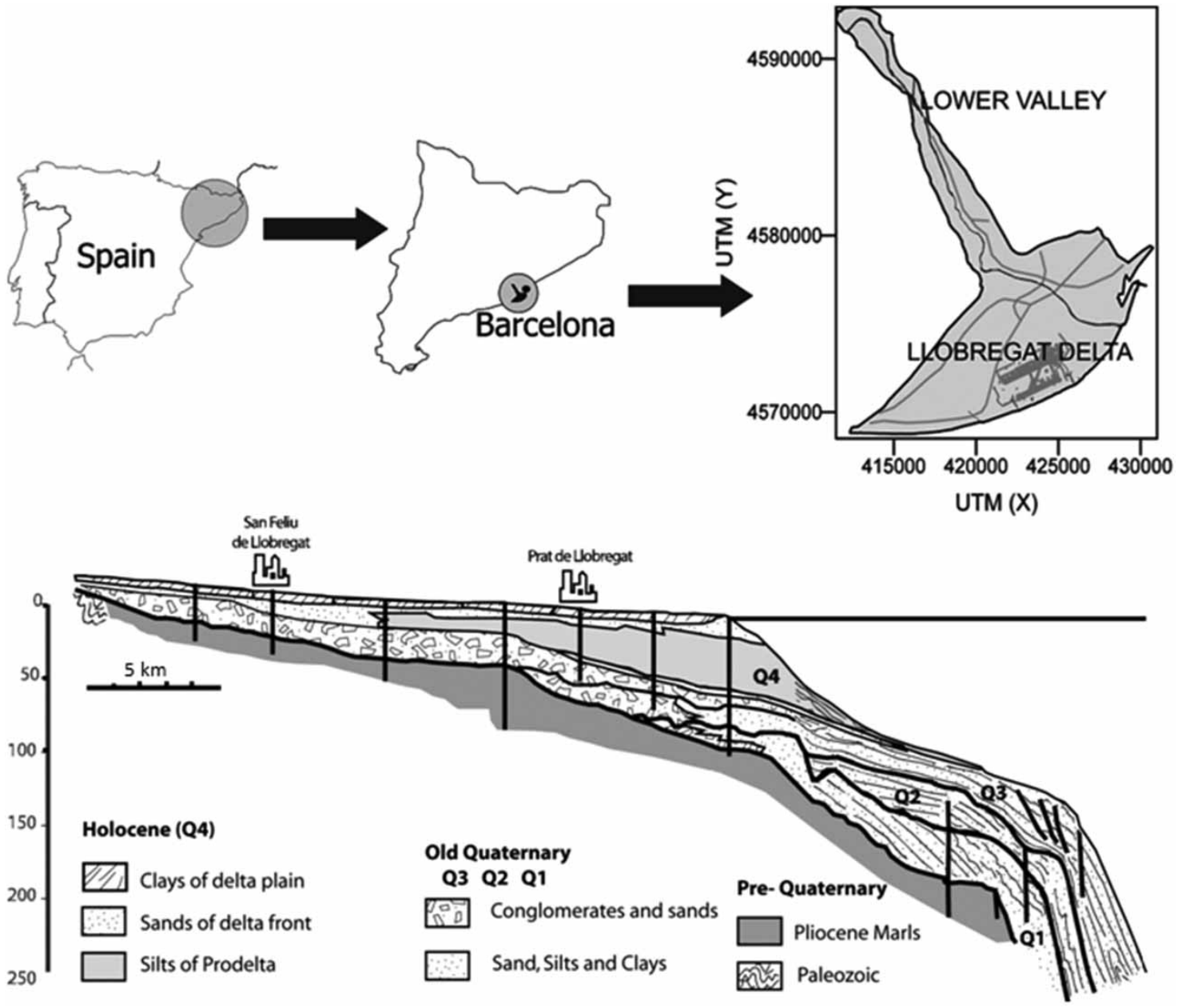

Figure 1 | Location of the Llobregat delta and lower valley and geological cross-section perpendicular to the coast of the emerged and submerged Llobregat delta (from Simó et al. 2005). The main aquifer is formed by the thin layer below the Q4 silts and the Q3 upper gravels.

Agbar (the main company supplying water) are carrying out various artificial recharge activities to mitigate water scarcity in the area and trying to recover the good status of the groundwater bodies, as is required by the European Water Framework Directive (Niñerola et al. 2009).

The most important project to improve the quality of the aquifer is the construction of the injection hydraulic barrier using reclaimed water (Ortuño et al. 2008). The main objective is to halt the advance of seawater intrusion. The barrier was implemented in two phases (Figure 3): phase I had an injection flow of $2,400 \mathrm{~m}^{3} /$ day in 4 wells, and phase II had a total injection flow of $15,000 \mathrm{~m}^{3} /$ day and incorporated 11 additional injection wells. Phase I started in March 2007 and phase II in April 2010. The functioning of the barrier stopped in July 2011 and, at present, the system is temporarily not operative.

\section{Injection water and quality control}

The injection water is reclaimed water from the Baix Llobregat waste water treatment plant (WWTP). Water is subjected to secondary treatment with nitrification and denitrification processes, followed by tertiary treatment. It consists of ballasted coagulation-flocculation, lamellar decantation, filtration and disinfection. Tertiary treated water is used for environmental uses (Cazurra 2008) and to feed the treatment plant for use in the hydraulic barrier. At the hydraulic barrier plant, prior to the distribution to the injection wells, water is subjected to ultrafiltration (UF), reverse osmosis (RO) and UV disinfection processes (Figure 4). Maximum production of water for injection is $15,000 \mathrm{~m}^{3} /$ day. Water is not chlorinated before injection due to the potentially harmful effects and the possible appearance of trihalomethanes in the aquifer. Ultrafiltration is performed to guarantee constant 


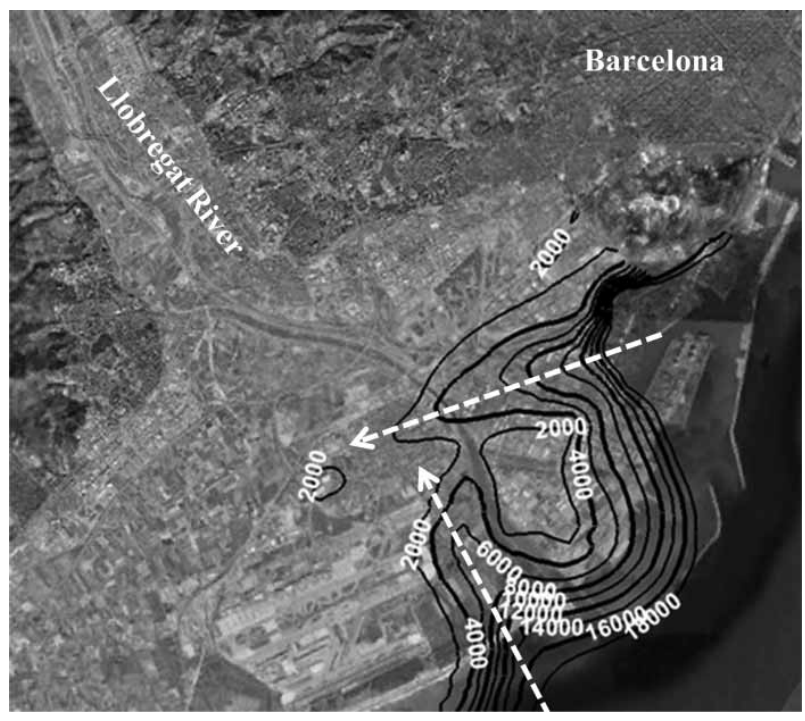

Figure 2 | Chloride concentration (mg/L) of the Llobregat delta main aquifer in 2007, showing the area intruded by seawater and the two main intrusion fronts. Seawater intrusion currently extends over one-third of the delta area, mostly following the preferential pathways shown by the arrows.

stability of microbiological quality (Gómez et al. 2006), to prevent physical clogging in the injection wells, and to extend the functional life of RO membranes. Reverse osmosis is necessary to reduce salinity, as the tertiary treatment water usually contains more than $600 \mathrm{mg} / \mathrm{L} \mathrm{Cl}^{-}$. High salinity concentrations are due to upstream saline water discharges into the Llobregat river basin, especially from current and past potash mine activity. Groundwater chloride content unaffected by seawater intrusion is about $350 \mathrm{mg} / \mathrm{L}$, which is the target value. $\mathrm{RO}$ is performed to $35-50 \%$ of the ultrafiltered water, and the percentage is optimized to achieve the target value of chloride content in the injected water. The concentrate from the RO is disposed into the sea through submarine outfall from the WWTP.

The quality requirements for aquifer recharge in Spain are issued by the Decree 1620/2007. Accordingly, electrical conductivity, $\mathrm{pH}$, temperature, ammonia and turbidity of the injected water are obtained continuously and automatically recorded. Also, biological and chemical parameters (nematodes, Escherichia coli, $\mathrm{P}, \mathrm{N}, \mathrm{Cl}, \mathrm{NO}_{3}$, $\mathrm{NH}_{4}$ and TOC) are monitored weekly or every 2 weeks. Major elements, metals, and volatile organohalogenated compounds are analyzed on a bimonthly basis. In addition, a complete analysis of all the Drinking Water Quality Regulation parameters is performed once a year, required by the Sanitation Authority.

Injection during phase I began on 26 March 2007. By May 2011 around $4 \mathrm{Mm}^{3}$ of reclaimed water had been injected. Average values of injected water were $347 \mathrm{mg} / \mathrm{L}$ for $\mathrm{Cl}^{-}, 1,849 \mathrm{mS} / \mathrm{cm}$ for electrical conductivity, 7.43 for $\mathrm{pH}$, and $<0.09$ NTU for turbidity. Water temperature was measured in the injection wells and ranged between $14{ }^{\circ} \mathrm{C}$ in winter and $29^{\circ} \mathrm{C}$ in summer. To date, coliforms, E. coli, Clostridium perfringens, nematodes or organochloride compounds have not been detected, and injection water complies with the Drinking Water Quality Regulation requirements.

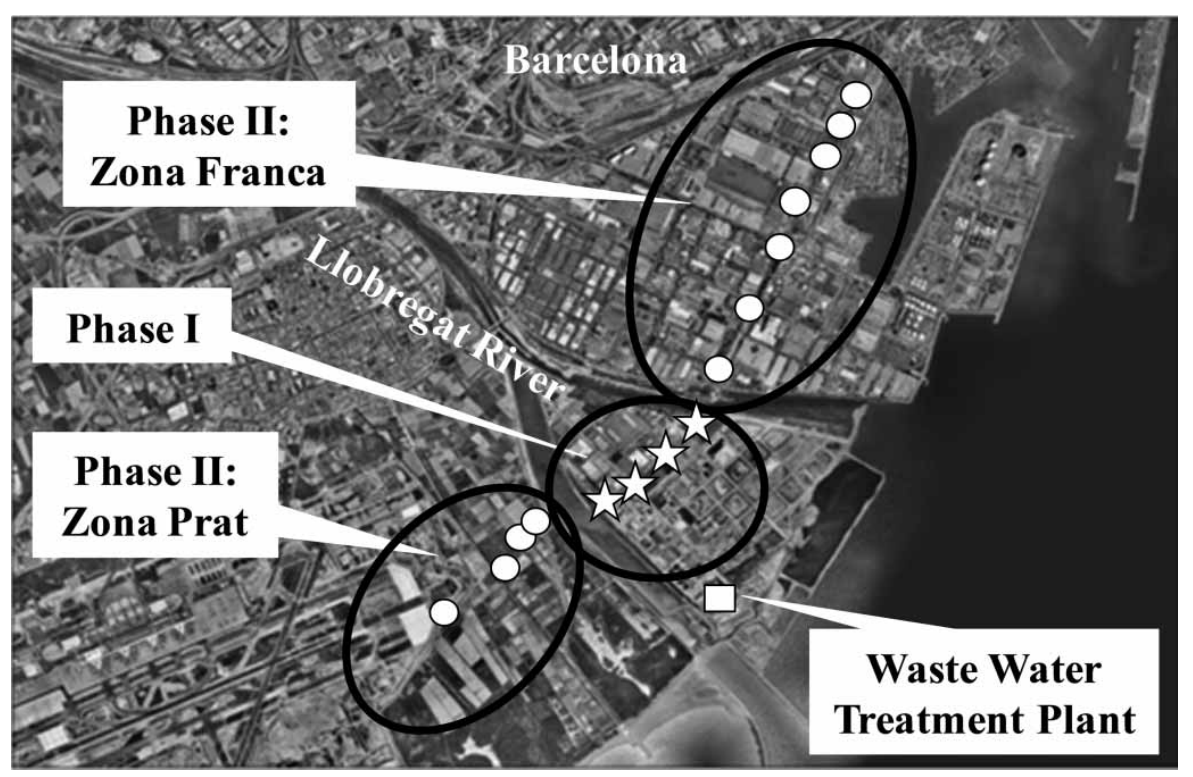

Figure 3 | Injection wells of the full hydraulic barrier (phases I and II) and location of the El Prat waste water treatment plant. 


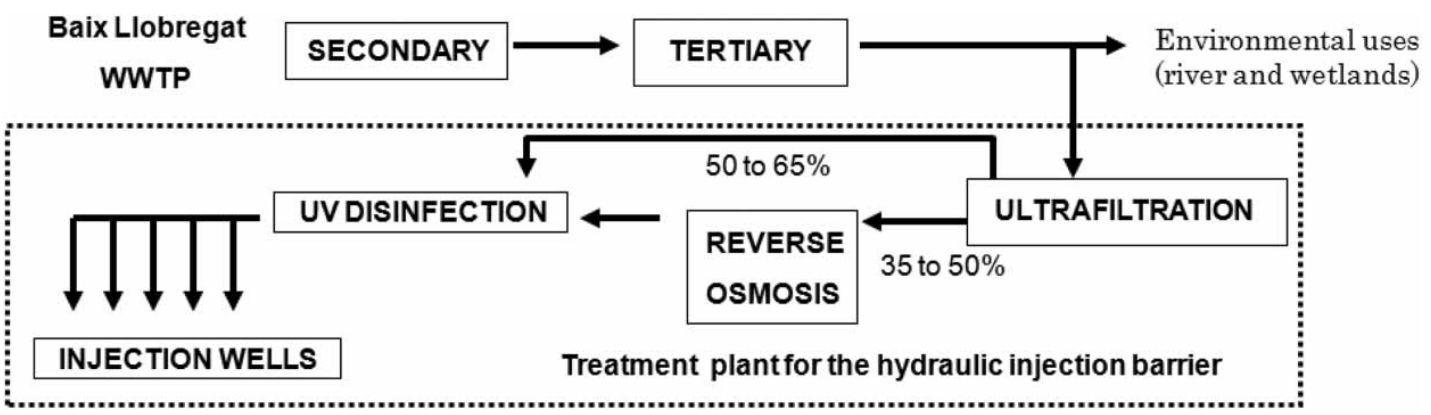

Figure 4 | Water treatment prior to injection into the aquifer. The injected water is reclaimed water from the tertiary effluent of the Baix Llobregat waste water treatment plant (WWTP, Barcelona, Spain), after ultrafiltration, reverse osmosis and UV disinfection.

\section{Injection wells}

Fifteen injection wells located $1 \mathrm{~km}$ inland following a parallel line of approximately $6 \mathrm{~km}$ (Figure 3) were drilled and completed for the hydraulic barrier (4 in phase I and 11 in phase II). Wells are $70 \mathrm{~m}$ deep and penetrate the complete thickness of the main confined aquifer along the barrier. They are equipped on the surface with flowmeters, automated electrovalves to maintain constant flow, and downhole sensors of water level, temperature and electrical conductivity. The injected volume, electrical conductivity, water temperature and well hydraulic head are recorded every hour. Wells are controlled remotely from the barrier's water treatment plant building.

The hydraulic barrier is operated to maintain the aquifer dynamic head in wells from 1 to $3 \mathrm{~m}$ above sea level (asl). Each well has its own injection flow rate that depends on local aquifer characteristics and the static aquifer head. As current groundwater heads are high in the main aquifer, the operation objectives can be met with a percentage of the total injection volume.

Preventive maintenance has been installed to avoid clogging of the well screen and surroundings. This is done through backflushing with submersible electropumps in 12 wells and compressed-air pumping devices in three wells. Maintenance is carried out periodically in a brief period of time in which water discharge is three times the volume of the injection. No decrease of well efficiencies (flow/head increase) has been detected so far. This is attributed to the high quality of the injected water, as well as to the strict cleaning program.

\section{Aquifer monitoring network}

The complete aquifer monitoring network consists of existing wells and piezometers, as well as 17 new boreholes constructed in the framework of the barrier project.
During the first phase, eight monitoring points were available, covering $3 \mathrm{~km}^{2}$ (Figure 5). Currently there are 37 monitoring points (17 new piezometers and 20 existing wells) covering $30 \mathrm{~km}^{2}$. All monitoring points are sampled and chemical analyses are carried out to determine major elements, nitrogen compounds, metals and organochlorine compounds. The 17 new piezometers also have a permanent sensor that records water level, temperature and electrical conductivity of the aquifer at hourly intervals.

\section{AQUIFER IMPROVEMENT AND BARRIER EFFICIENCY}

The analytical results and field monitoring data of the aquifer during phase I of the project show highly positive results (Ortuño et al. 2009). Since 2007, in the eight monitoring points there has been a progressive decrease of chlorides,

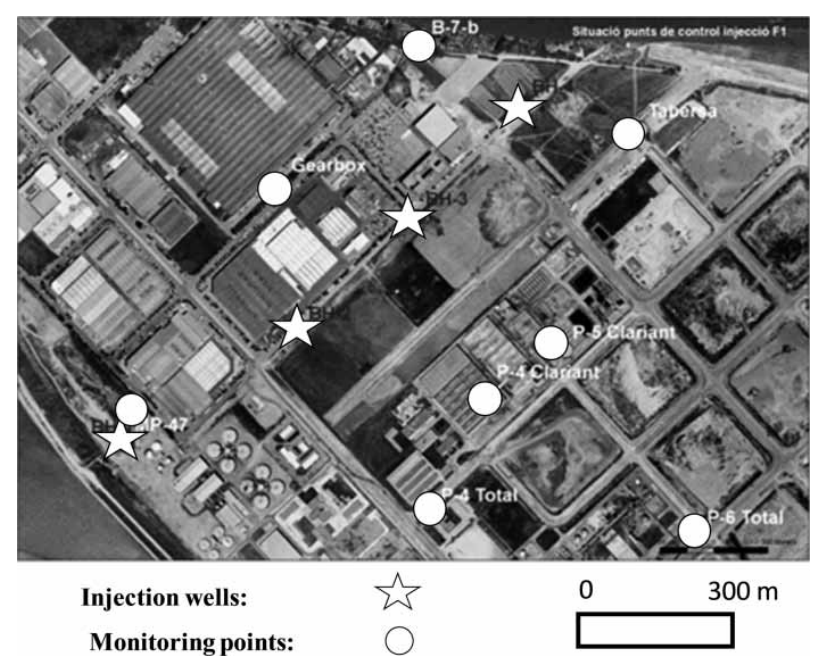

Figure 5 | Phase I aquifer monitoring network. The monitoring network (eight stations) covers a radius of less than $1 \mathrm{~km}$ around the four injection wells. 


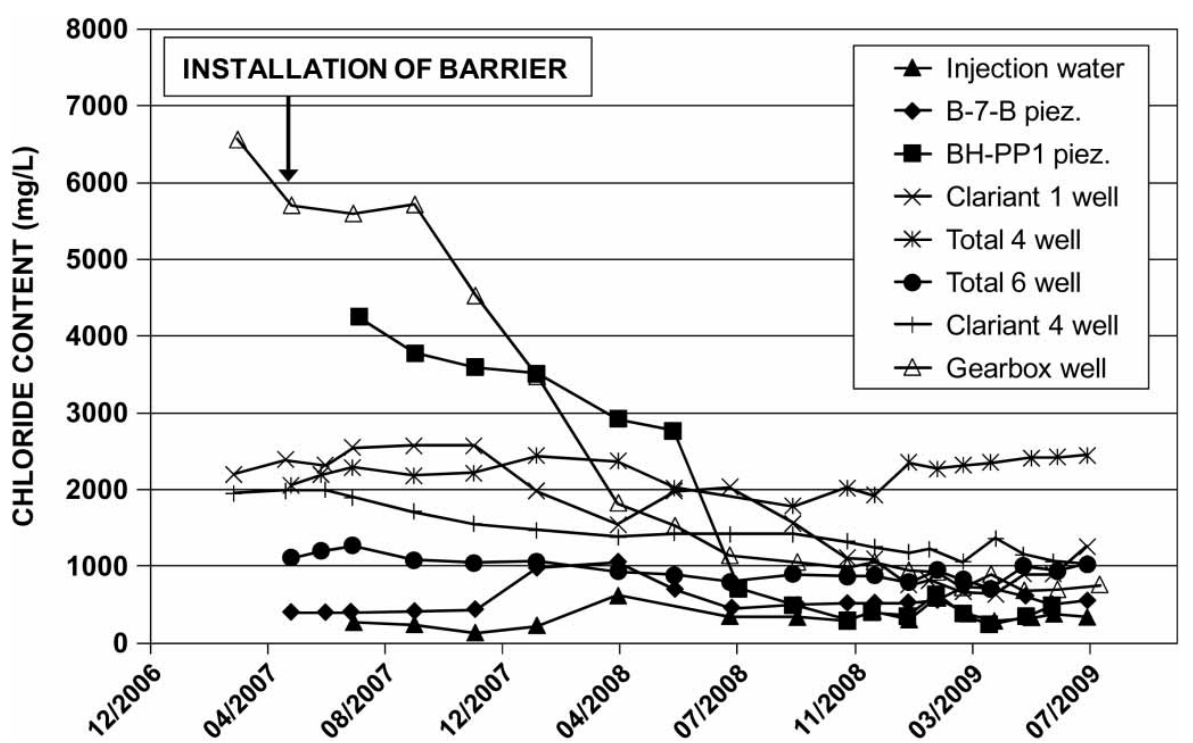

Figure 6 | Groundwater chloride evolution in the monitoring points in the phase I of the hydraulic barrier. Analytical results and field monitoring data also show a decrease in the content of sodium, calcium, magnesium, iron and ammonium content in the aquifer, and a slight nitrate increase due to its presence in the injected water.

sodium, calcium, magnesium, iron and ammonium contents (Figure 6). A slight nitrate increase has been observed, due to its presence in the injected water. Bicarbonate content is constant. The area influenced by recharged water ranges from 1 to $2 \mathrm{~km}$ around the injection wells, and it is irregular. This is because groundwater flow from the seaside is halted or has been greatly reduced, while recharged water readily moves inland toward the pumped areas. The barrier has a clear oxidizing effect on the otherwise highly reducing aquifer ambient. So far, a clear redox perturbation is only observed in one of the piezometers located at a distance of $4 \mathrm{~m}$ of the injection well. The other boreholes in the local monitoring network, located in a range of $200 \mathrm{~m}$ from the injection points, show what seem to be the previous reducing conditions.

\section{INVESTMENT AND EXPLOITATION COSTS OF THE BARRIER}

The total investment for the construction of the Llobregat hydraulic barrier amounts to $€ 23$ million, including the treatment plant which produces $15,000 \mathrm{~m}^{3}$ /day of reclaimed water, more than $7 \mathrm{~km}$ of conduction pipes, 15 injection wells (drilling and equipment), and 17 new piezometers with remote-control data systems. The investment has been made by the ACA, the Spanish Ministry of the Environment and Rural and Marine Affairs, and the European Commission.
Total operation costs, fixed and variable, range from 0.14 to $0.18 € / \mathrm{m}^{3}$, depending on the total injection flow. Variable costs are $0.04 € / \mathrm{m}^{3}$ for chemicals and $0.05 € / \mathrm{m}^{3}$ for energy (treatment plant and pumping), with a total of $0.09 € / \mathrm{m}^{3}$. Fixed annual costs (about 190,000€) range from 0.05 to $0.09 € / \mathrm{m}^{3}$, and are comprised of staff, treatment plant maintenance and well maintenance.

\section{CONCLUSIONS AND DISCUSSION}

A positive hydraulic barrier injecting highly treated reclaimed water into the aquifer has been constructed in order to stop the advance of the seawater intrusion in the main Llobregat delta aquifer, near Barcelona (Spain). It works by injecting water into 15 wells located in the saline water fronts, following a parallel line along the coast. Injection produces the rise of the groundwater head to halt seawater penetration inland.

The first phase of the project has been functioning for three years with four injection wells and eight observation points, showing highly positive results. Aquifer recharge operations that utilize reclaimed water normally experience some degree of well clogging (Pavelic et al. 2007), defined as a decrease in the injection capacity due to mechanical, chemical, and biological processes. Well clogging has not been observed, and this is attributed to two factors: (1) the high water injection quality, and (2) the strict well cleaning program. Water quality affects clogging rates (Pérez-Paricio \& 
Carrera I999; Pavelic et al. 2007), and the very low levels of turbidity in the injection water $(<0.1 \mathrm{NTU})$, after ultrafiltration and reverse osmosis processes, have certainly helped to prevent or delay the clogging. Related to the cleaning program, the wells have been operated intermittently to prevent physical clogging caused by the accumulation of particles on the well bore (Beek et al. 2009). This has been done through backflushing, stopping the injection every two weeks for a short period of time (usually 15 minutes) with the objective of removing the particles accumulated during the preceding abstraction period. It seems that, in our case, this program works well.

Substantial improvement of groundwater quality has been observed in eight wells located in a radius of less than $1 \mathrm{~km}$ around the four injection points in phase I. Before injection, average chloride content of the 8 wells was 2,634 mg/L in March 2007, decreasing to $1,018 \mathrm{mg} / \mathrm{L}$ in 3 years of operation. Industrial wells of three local companies have reduced chloride content of groundwater from 2,575 to $634 \mathrm{mg} / \mathrm{L}$, from 1,269 to $705 \mathrm{mg} / \mathrm{L}$, and from 6,565 to $679 \mathrm{mg} / \mathrm{L}$, respectively. A progressive decrease of sodium, calcium, magnesium, iron and ammonium content has also been observed in the monitoring points, and a slight nitrate increase. Nitrate is not present in the aquifer and the injection water has an average value of $9.4 \mathrm{mg} / \mathrm{L}$ $\mathrm{NO}_{3}^{-}$. However, the nitrogen cycle and nitrogen transformations in costal aquifers and freshwater-saltwater mixing zones are complex (Santoro 20I0).

Total operation costs of the hydraulic barrier have been calculated after three years of operation, and range from 0.14 to $0.18 € / \mathrm{m}^{3}$, depending on total injection flow. The injection rate depends on the regional hydraulic head of the aquifer. Generally, groundwater levels are below sea level in the Llobregat delta aquifer. If the groundwater regional heads are high (i.e. from -5 to $0 \mathrm{~m}$ asl), the operation objectives can be met with only a fraction of the total injection volume, and the total cost of operation is less. On the contrary, if the aquifer groundwater heads are very low, it may be necessary to inject all the water production. The operation cost per unit of the hydraulic barrier exploitation by injecting water into the aquifer with an excellent quality and which will afterwards be recovered in a large proportion by the delta supply wells, is lower than that of seawater desalination. It also prevents the further deterioration of the quality of the groundwater.

Phase II of the hydraulic barrier was in operation from April 2010 to July 2011. Several years of operation will be needed, coupled with other actions of aquifer artificial recharge, to fully reduce the salinity of the Llobregat aquifer
(Abarca et al. 2006). However, the results of phase I show that the concept and technology of the hydraulic barrier are capable of halting or retarding the advance of the saline water fronts in the main Llobregat delta aquifer.

\section{ACKNOWLEDGEMENTS}

This project was funded by the Catalan Water Agency (ACA), the Spanish Ministry of the Environment and Housing and the European Commission. The authors are grateful to comments and suggestions by two anonymous reviewers and the editors that helped to improve the manuscript. The authors would also like to thank Josep Maria Niñerola, Joan Jovés, Gabriel Borràs, AREMA and the community of end users of the Llobregat delta aquifers (CUADLL) for their support and help.

\section{REFERENCES}

Abarca, E., Vázquez-Suñé, E., Carrera, J., Capino, B., Gámez, D. \& Batlle, F. 2006 Optimal design of measures to correct seawater intrusion. Water Resources Research 42, W09415.

Beek, C. G. E. M., Breedveld, R. J. M., Juhász-Holterman, M., Oosterhof, P. J. \& Stuyfzand, P. J. 2009 Cause and prevention of well bore clogging by particles. Hydrogeology Journal 17, 1877-1886.

Cazurra, T. 2008 Water reuse of south Barcelona's wastewater reclamation plant. Desalination 218 (2008), 43-51.

Custodio, E. 198I Sea water encroachment in the Llobregat and Besós areas, near Barcelona (Catalonia, Spain). In: Intruded and Fosil Groundwater of Marine Origin. Sveriges Geologiska Undersökning. Uppsala. Rapporter och Meddelanden, 27, 120-152.

Custodio, E. 2008 Acuíferos detríticos costeros del litoral mediterráneo penínsular: valle bajo y delta del Llobregat. Monográfico: Las Aguas Subterráneas. Rev. Assoc. Española Enseñanza de las Ciencias de la Tierra. Madrid 15 (3), 295-304.

Custodio, E. 20Io Coastal aquifers of Europe: an overview. Hydrogeology Journal 18, 269-280.

Gámez, D. 2007 Sequence stratigraphy as a tool for water resource management in alluvial coastal aquifers: application to the Llobregat delta (Barcelona, Spain). Doctoral Thesis. Department of Geotechnical Engineering and Geo-Sciences (ETCG). Technical University of Catalonia (UPC). 1-177 + An.

Gómez, M., Plaza, F., Garralón, G., Pérez, J. \& Gómez, M. A. 2006 A comparative study of tertiary wastewater treatment by physico-chemical-UV process and macrofiltrationultrafiltration technologies. Desalination 202 (1-3), 369-376.

Iríbar, V. 1992 Evolución hidroquímica e isotópica de los acuíferos del Baix Llobregat. Doctoral Thesis. Department of 
Geochemistry, Petrology and Geology. University of Barcelona (UB).

Iribar, V. \& Custodio, E. 1992 Advancement of seawater intrusion in the Llobregat delta aquifer. In: Study and Modelling of Salt Water Intrusion. CIMNE-UPC. Barcelona, pp. 35-50.

Iríbar, V., Carrera, J., Custodio, E. \& Medina, A. 1997 Inverse modelling of seawater intrusion in the Llobregat delta deep aquifer. Journal of Hydrology 198 (1-4), 226-247.

Manzano, M. I993 Génesis del agua intersticial del acuitardo del Delta del Llobregat: origen de los solutos y transporte interactivo con el medio sólido. Doctoral Thesis. Department of Geotechnical Engineering and Geo-Sciences (ETCG). Technical University of Catalonia (UPC).

Marqués, M. A. 1984 Las formaciones cuaternarias del delta del Llobregat. Doctoral Thesis. Department of Geological Science, University of Barcelona (UB).

Niñerola, J. M., Queralt, E. \& Custodio, E. 2009 Groundwater Monitoring. Chapter 5.7: Llobregat delta aquifer. (Ph. Quevauviller, A. -M. Fouillac, J. Grath \& R. Ward, eds). John Wiley \& Sons Ltd, 289-301.

Ortuño, F., Niñerola, J. M., Teijon, G. \& Candela, L. 2008 Desarrollo de la primera fase de la barrera hidráulica contra la intrusión marina en el acuífero principal del Delta del Llobregat. IX National Symposium on Hydrogeology, Elche (Spain).
Ortuño, F., Niñerola, J. M., Armenter, J. L. \& Molinero Huguet, J. 2009 La barrera hidráulica contra la intrusión marina y la recarga artificial en el acuífero del Llobregat (Barcelona, España). Boletín Geológico y Minero, IGME, 120 (2), 235250, ISSN: 0366-0176.

Pavelic, P., Dillon, P. J., Barry, K. E., Vanderzalm, J. L., Correll, R. L. \& Rinck-Pfeiffer, S. M. 2007 Water quality effects on clogging rates during reclaimed water ASR in a carbonate aquifer. Journal of Hydrology 334, 1-16.

Pérez-Paricio, A. \& Carrera, J. 1999 Clogging Handbook. EU Project on Artificial Recharge of Groundwater, Research Program on Environment and Climate, Contract ENV-CT95-0071.

Santoro, A. E. 20Io Microbial nitrogen cycle at the saltwaterfreshwater interface. Hydrogeology Journal 18, 187-202.

Simó, J. A., Gámez, D., Salvany, J. M., Vazquez-Suñé, E., Carrera, J., Barnolas, A. \& Alcala, F. J. 2005 Arquitectura de facies de los deltas cuaternarios del río Llobregat, Barcelona, España. Geogaceta 38, 171-174.

Vázquez-Suñé, E., Abarca, E., Carrera, J., Capino, B., Gámez, D., Pool, M., Simó, T., Batlle, F., Niñerola, J. M. \& Ibáñez, X. 2006 Groundwater modelling as a tool for the European Water Framework Directive (WFD) application: the Llobregat case. Physics and Chemistry of the Earth 31 (17), 1015-1029.

First received 16 January 2012; accepted in revised form 13 June 2012 